\title{
Foscarnet Effects on the Rat Pregnancy Outcome
}

\author{
Efectos del Foscarnet Sobre la Rata Preñada \\ ${ }^{*}$ Cícero Venneri Mathias; ${ }^{* *}$ Manuel de Jesus Simões; ${ }^{* *}$ Abes Mahmed Amed; ${ }^{* * *}$ Ricardo Martins Oliveira-Filho; ${ }^{*}$ Camila \\ Fernandes Venneri Mathias; ${ }^{* *}$ Ricardo dos Santos Simões \& ** Luiz Kulay Júnior
}

MATHIAS, V. C. ; SIMÕES, M. J.; AMED, A. M.; OLIVEIRA-FILHO, R. M.; MATHIAS, V. C. F. ; SIMÕES, R.S.; KULAY Jr., L. Foscarnet effects on the rat pregnancy outcome. Int. J. Morphol., 23(2):137-140, 2005.

SUMMARY: There are few long-term data on which to base decisions of drug management of HIV infection in pregnancy. The determination of safe medications must take into consideration the need for certain drugs and the possibility of inadvertent fetal exposure because of unplanned pregnancies. The aim of this study was to evaluate the effects of foscarnet on the entire period of rat pregnancy. Female pregnant rats were randomly assigned to four treatment groups $(\mathrm{n}=10)$ : one control $(\mathrm{C})$ - treated with the drug vehicle (bidestilled water) and three experimental groups (E1, E2 and E3) - treated with 180, 360 or $720 \mathrm{mg} / \mathrm{Kg}$ of foscarnet, respectively. Rats were treated by gavage once daily. The treatment period extended from the first until the 20th day of pregnancy. Body weights were recorded weekly along this period. At term, the rats were sacrificed, the implantation sites and the number of fetuses and resorptions were recorded. The fetuses were evaluated for externally visible abnormalities under a stereomicroscope. No differences in body weights among the groups were observed; however, foscarnettreated rats showed reduced fetal and placental weights. The incidence 137of resorptions and major malformations (shortening of limbs) in the E3 group was significantly raised. Foscarnet treatment during the entire period of rat pregnancy can produce definite toxic effects, mainly on the placental and fetal compartments.

KEY WORDS: Antiretroviral drugs; Foscarnet; Pregnancy; Rat.

\section{INTRODUCTION}

The incidence of human immunodeficiency virus (HIV) infection is raising over the world, mainly in poor parts of Eastern Europe, Asia and sub-Saharan Africa (Bicego et al., 2003; Goodwin et al., 2004). In addition, the great number of HIVinfected pregnant women makes this disease to be an important public health concern around the world (Brettle \& Leen, 1991). Therefore, special attention is given to the subject of the perinatal transmission of HIV, one of the strategies in this issue being the use of antiretroviral drug administration during pregnancy in order to prevent vertical infection (Connor et al., 1994; Tuntland et al., 1999). In fact, antiviral agents offer significant reduction in the rate of mother-to-child HIV transmission (Connor et al.; Katz, 2003). However, antiretroviral drugs occasionally induce severe side effects and may not reach their therapeutic goals in some patients, for whom the survival expectance depends upon rapid access to new antiretroviral drugs and new therapeutic strategies (Gastaut, 2003; Volberding, 2003).

Foscarnet (trisodium phosphonoformate) is a synthetic pyrophosphate analogue which effectively acts against citomegalovirus and herpesvirus, being also an alternative against the HIV reverse transcriptase. Its antiviral activity is exerted through a selective inhibition at the pyrophosphate binding site of virus-specific DNA polymerases, at concentrations that do not affect host cellular DNA polymerases. Unfortunately, there are no adequate or well- controlled studies in pregnant women using foscarnet. It is known that its administration up to $75 \mathrm{mg} /$ day can cause some rat fetal malformations, such as skeletal anomalies (Watts, 1992).

Since the chronic effects of foscarnet during pregnancy were not fully studied as yet, this paper aims to contribute to this knowledge by evaluating the effects of its administration to pregnant rats in three dosage levels during the entire period of gestation.

\section{MATERIAL AND METHOD}

The experimental protocols were approved by the local Committee of Ethics on Animal Experimentation. Adult virgin

* Department of Obstetrics and Ginaecology - School of Medicine, Fundação ABC, São Paulo (SP), Brazil.

** Federal University of São Paulo School of Medicine (UNIFESP-EPM), São Paulo (SP), Brazil.

**** University of São Paulo Institute of Biomedical Sciences (USP), São Paulo (SP), Brazil. 
female EPM-1 Wistar rats, weighing about $200 \mathrm{~g}$, were selected after three regular consecutive estrous cycles and kept under specific pathogen-free conditions. The animals were allowed free access to a standard Purina ${ }^{\circledR}$ pelleted diet and water and were maintained at $19-22^{\circ} \mathrm{C}$, in a 12 -h light/dark cycle (lights on at 7:00 a. m.). The rats were mated in the proportion of 2 females for one male, during $2 \mathrm{~h}$. The day 'zero' of pregnancy was considered to be the first 24-h period after the mating by the finding of spermatozoa in vaginal smears (Hamilton \& Wolfe, 1938).

Forty pregnant rats were then randomly divided into four groups with ten rats each, one control (C) and three experimental drug-treatment groups (E1, E2 and E3). Control animals were given the drug vehicle (bidestilled water) from day 0 up to the 20 th day of pregnancy. The experimental groups were given $180 \mathrm{mg} / \mathrm{Kg}$ (E1), $360 \mathrm{mg} / \mathrm{Kg}$ (E2) or $720 \mathrm{mg} / \mathrm{Kg}$ (E3) per day of foscarnet, respectively, during the entire period of pregnancy. The drug (foscarnet trisodium salt, hexahydrated, Astra Laboratory) was purchased as a solution for intravenous administration containing $24 \mathrm{mg} /$ $\mathrm{ml}$ of foscarnet. Drug and vehicle administrations were done once a day (at 10:00h a.m.) by intraperitoneal route. Body weights were recorded on the «zero» and the 7th, 14th and 20th days of pregnancy.

At term (20th day), the rats were killed by decapitation under deep anesthesia using $1 \mathrm{mg} / \mathrm{Kg}$ ketamin. Upon laparotomy and opening of the uterine horns, the following items were recorded: number of implantations and resorptions, number of placentae, placental and fetal weights, and number of intrauterine deaths. Fetal malformations were studied with a stereomicroscope.

A resorption is herein defined as the finding of endometrial sites with an appended amorphous mass without a fetus. The number of implantations is defined as the results of the total number of placentae with fetuses plus the total number of resorptions.

The results were analyzed by one-way analysis of variance (ANOVA) and the Tukey-Kramer's multiple comparisons test. A 2.01 version of GraphPad InStatTM software was used for this purpose. The differences were considered statistically significant when $p<0.05$. The Fisher's exact test was used for analysis of contingency tables.

\section{RESULTS AND DISCUSSION}

The weight of all females at mating averaged 213.57 $\pm 12.05 \mathrm{~g}$ (mean $\pm \mathrm{SD})$. Table I summarizes the rat body weight gain during the experiment. At term, the mean body weight of all animals averaged $291.67 \pm 20.50 \mathrm{~g}$, and no significant differences were noticed among the groups (Fig. 1). The results of pregnancy outcome after treatments are seen in Table II. The mean fetal weight in the E3 group was significantly decreased regarding the other groups $(\mathrm{p}<0.001)$. The placental weight was reduced in the group treated with the largest dose of foscarnet (group E3), and this coincided with a significantly increased number of foetal resorptions (Table II). In addition, there has been a significant number of foetal limb shortenings in that group.

One aspect of concern during antiviral therapy with foscarnet is that, unfortunately, there are no adequate or wellcontrolled studies in pregnant women using foscarnet; moreover, there are reports of nephrotoxicity (36\%) and liver damage (5\%) in humans (Sjovall et al., 1988, 1989; Fanning et al., 1990; Jayaweera, 1997). The administration of this drug up to $75 \mathrm{mg} /$ day per day may cause some rat fetal malformations, such as skeletal anomalies (Watts).

Since no reports in the literature were found about the effects foscarnet on the body weight gain of pregnant rats, this aspect was examined in our animals. Table I and Fig. 1 show the body weight gain of rats during pregnancy throughout the experimental period. Similarly to what occurs in normal rats, it should be noticed that all groups reached their fastest weight gain in the last third of pregnancy, but no differences were detected with regard to the control group.

The drug administration protocol used herein corresponded to a foetal exposition to foscarnet during the entire gestational period, comprising the phases of cell hyperplasia, hyperplasia/hypertrophy and hypertrophy (Winick, 1970).

In the course of foscarnet use for the treatment of cytomegalovirus retinitis in patients with AIDS, Jacobson et al. (1989) and Lehoang et al. (1989) reported the occurrence of hypomagnesemia, hypocalemia, hypocalcemia and hypophosphatemia. Accordingly, Paspaliaris et al. (1993) showed that foscarnet inhibits vascular smooth muscle contraction by inhibiting calcium release from intracellular stores, and it seems that the foscarnet molecule binds preferentially magnesium ions (Noormohamed et al., 1996). The actions exerted by foscarnet at the mineral metabolism level could help to explain, at least in part, why pregnant rats treated during the entire period of gestation display deleterious effects, mainly at placental and foetal compartments. Accordingly, it is highly conceivable that the shortening of foetal limbs seen in the group E3 may relate to the interference of foscarnet with calcium ions. 
Table I. Body weights of pregnant rats, control (C) or treated with foscarnet (E).

\begin{tabular}{clccc}
\multicolumn{5}{c}{ Groups } \\
$\begin{array}{l}\text { Period of } \\
\text { pregnancy }\end{array}$ & Control & $\mathrm{E}_{1}$ & $\mathrm{E}_{2}$ & $\mathrm{E}_{3}$ \\
$\quad$ & & $(180 \mathrm{mg} / \mathrm{Kg})$ & $(360 \mathrm{mg} / \mathrm{Kg})$ & $(720 \mathrm{mg} / \mathrm{Kg})$ \\
Initial & $214.93 \pm 11.68$ & $220.10 \pm 12.23$ & $209.54 \pm 10.10$ & $209.72 \pm 17.97$ \\
1 th day & $229.60 \pm 10.67$ & $237.68 \pm 16.01$ & $226.59 \pm 10.40$ & $223.00 \pm 19.84$ \\
20th dy & $258.62 \pm 11.42$ & $256.80 \pm 11.69$ & $253.71 \pm 12.56$ & $244.68 \pm 27.18$ \\
\hline
\end{tabular}

During the entire period of pregnancy the control rats received destilled water $(1 \mathrm{ml})$; experimental rats (E1, E2 and E3) were treated with the indicated doses of foscarnet, once daily by gavage. Weights are expressed in grams (mean $\pm \mathrm{SD}$ ). There are no statistical differences among the groups within the same gestational period.

Table II. Effects of foscarnet on the rat pregnancy outcome.

\begin{tabular}{ccccc}
\hline & \multicolumn{4}{c}{ Groups } \\
\cline { 2 - 5 } & Control & $\mathrm{E}_{1}$ & $\mathrm{E}_{2}$ & $\mathrm{E}_{3}$ \\
\cline { 2 - 5 } & & $(180 \mathrm{mg} / \mathrm{Kg})$ & $(360 \mathrm{mg} / \mathrm{Kg})$ & $(720 \mathrm{mg} / \mathrm{Kg})$ \\
\hline Implantations & $8.50 \pm 3.10$ & $6.20 \pm 3.60$ & $9.30 \pm 3.40$ & $10.60 \pm 2.40$ \\
Resorptions & 0 & 0 & $0.10 \pm 0.32$ & $0.90 \pm 1.10^{*}$ \\
Living foetuses & $8.50 \pm 3.10$ & $6.20 \pm 3.60$ & $9.20 \pm 3.40$ & $8.70 \pm 2.40$ \\
Fetal weight $(\mathrm{g})$ & $4.10 \pm 0.60$ & $3.60 \pm 0.50$ & $3.70 \pm 0.40$ & $3.10 \pm 0.20^{*}$ \\
Placental weight $(\mathrm{g})$ & $0.71 \pm 0.07$ & $0.74 \pm 0.06$ & $0.63 \pm 0.09$ & $0.60 \pm 0.08^{*}$ \\
Foetal malformations $^{1}$ & 0 & $0,10 \pm 0,32$ & 0 & $0.60 \pm 0.08^{*}$ \\
\hline
\end{tabular}

During the entire period of pregnancy control rats received destilled water (1 ml); experimental rats (E1, E2 and E3) were treated with the indicated doses of foscarnet, once daily by gavage. Weights are expressed in grams (mean \pm SD). 1Limb shortening. ${ }^{*} \mathrm{p}<0.001$ with regard to the others groups; ${ }^{*} \mathrm{p}<0.05$ with regard to $\mathrm{C}$ and $\mathrm{E} 1$.

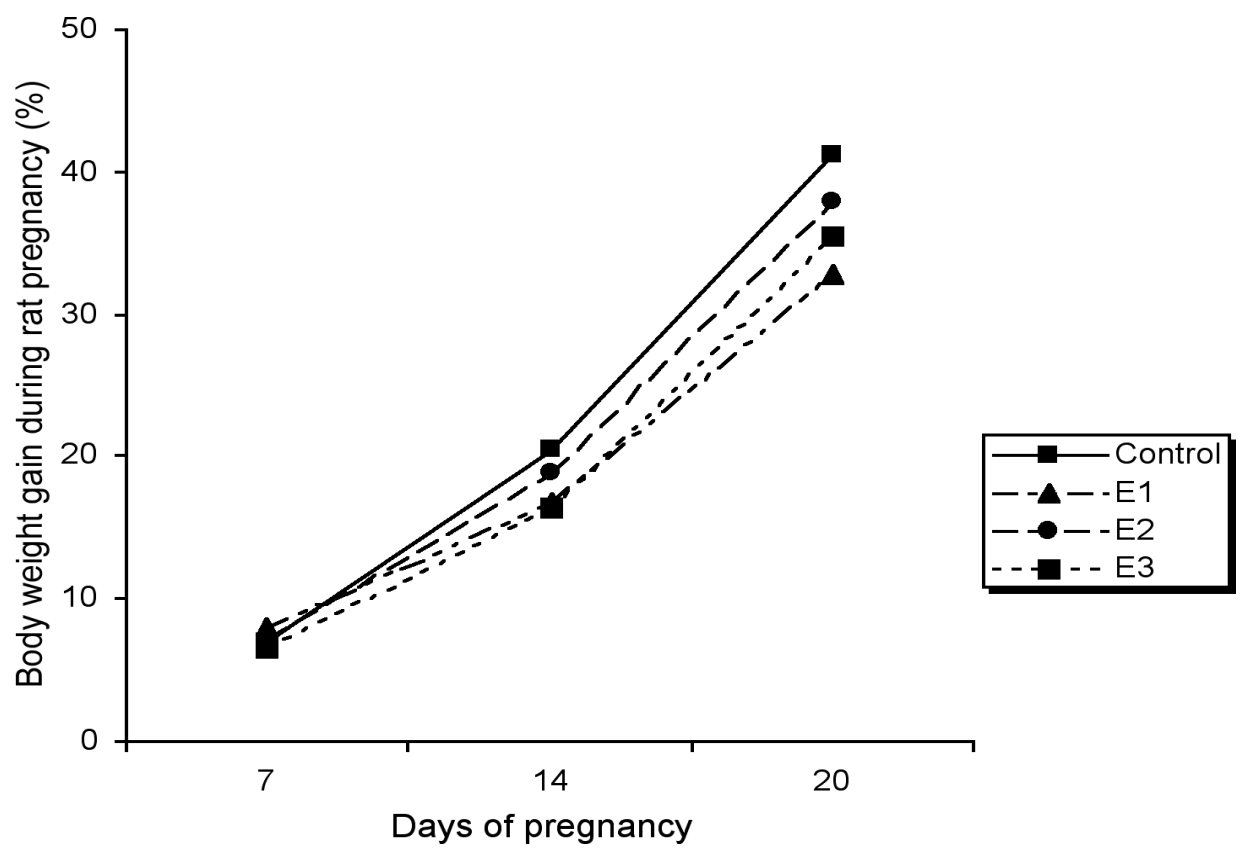

Fig. 1. Evolution of body weight gain during pregnancy in rats, control $(\mathrm{C})$ or treated during the entire period of pregnancy with foscarnet $(\mathrm{E} 1=180 \mathrm{mg} / \mathrm{Kg} ; \mathrm{E} 2=360 \mathrm{mg} / \mathrm{Kg} ; \mathrm{E} 3=720 \mathrm{mg} / \mathrm{Kg}$ once a day, by gavage). Values are mean $\pm \mathrm{SEM}$ ( $\mathrm{n}$ $=10$ for every group) of percentual increments with regard to the initial weight (pregnancy day zero). No significant differences were detected among the groups. 
MATHIAS, V. C. ; SIMÕES, M. J.; AMED, A. M.; OLIVEIRA-FILHO, R. M.; MATHIAS, V. C. F. ; SIMÕES, R.S.; KULAY Jr., L. Efectos del foscarnet sobre la rata preñada. Int. J. Morphol., 23(2):137-140, 2005.

RESUMEN: Foscarnet es un inhibidor de la transcriptasis reversa del HIV que actúa en la síntesis del DNA. En este trabajo evaluamos los efectos crónicos del foscarnet durante la preñez de la rata albina. Ratas preñadas fueron distribuidas aleatoriamente en cuatro grupos ( $\mathrm{n}=10$ para cada grupo): uno control (C), tratadas con agua bidestilada, y tres experimentales (E1, E2 y E3), tratadas con 180, 360 o $720 \mathrm{mg} / \mathrm{Kg}$ al día de foscarnet. El fármaco y el vehículo (siempre $1 \mathrm{ml}$ ) fueron administrados una vez al día desde el día 0 hasta el día 20 de la gestación. Las ratas fueron pesadas semanalmente y sacrificadas al término de la preñez. No se observaron alteraciones significativas en cuanto al incremento de peso corporal entre los grupos. Sin embargo, las ratas tratadas con foscarnet (especialmente las de los grupos E2 y E3) presentaron reducciones del peso promedio de los fetos y de las respectivas placentas. La incidencia de reabsorciones y malformaciones (acortamiento de miembros) fue significativa en el grupo E3. Se concluye que la administración de foscarnet durante toda la preñez de la rata puede producir efectos tóxicos definidos, especialmente en los compartimientos placentario y fetal.

PALABRAS CLAVE: Fármacos antiretrovirales; Foscarnet; Preñez; Rata hembra.

\section{REFERENCES}

Bicego, G.; Rutstein, S. \& Johnson, K. Dimensions of the emerging orphan crisis in Sub-Saharan Africa. Soc. Sci. Med., 56:1235-47, 2003.

Brettle, R. P. \& Leen, C. L. S. The natural history of HIV and AIDS in women. AIDS, 5:1283-92, 1991.

Connor, E. M.; Sperling, R. S.; Gelber, R.; Kiselev, P.; Scott, G.; O’Sullivan, M. J.; VanDyke, R.; Bey, M.; Shearer, W.; Jacobson, R.L. et al. Reduction of maternal-infant transmission of human immunodeficiency virus type 1 with zidovudine treatment. Pediatric AIDS Clinical Trials Group Protocol 076 Study Group. N. Engl. J. Med., 331:1173-80, 1994.

Fanning, M. M.; Read, S. E.; Benson, M.; Vas, S.; Rachlis, A.; Kzousek, V.; Mortimer, C.; Harvey, P.; Schwartz, C. \& Chew, E. Foscarnet therapy of cytomegalovirus retinitis in AIDS. J. Acquir. Immune Defic. Syndr., 3:472-9, 1990.

Gastaut, J. A. The problems in France created by the HIV/AIDS epidemic at the onset of the third millennium. Presse Med., 32:268-75, 2003.

Goodwin, R.; Kwiatkowska, A.; Realo, A.; Kozlova, A.; Nguyen Luu, L.A. \& Nizharadze, G. Social representations of HIV/AIDS in five Central European and Eastern European countries: a multidimensional analysis. AIDS Care., 16:669-80, 2004.

Hamilton, J. B. \& Wolfe, J. M. The effect of male hormone substance upon birth and prenatal development in the rat. Anat Rec., 70:43340, 1938

Jacobson, M. A.; O’Donnell, J. J. \& Mills, J. Foscarnet treatment of cytomegalovirus retinitis in patients with the acquired immunodeficiency syndrome. Antimicrob. Agents Chemother. 33:736-41, 1989.

Jayaweera, D.T. Minimising the dosage-limiting toxicities of foscarnet induction therapy. Drug Saf., 16:258-66, 1997.

Katz, A. The evolving art of caring for pregnant women with HIV infection. J. Obstet. Gynecol. Neonatal. Nurs., 32:102-8, 2003.

Lehoang, P.; Girard, B.; Robinet, M.; Marcel, P.; Zazoun, I.; Matheron, S.; Rozenbaum, W.; Katlama, C.; Morer, I. \& Lemestedt, J.O.
Foscarnet in the treatment of cytomegalovirus retinitis in acquired immune deficiency syndrome. Ophthalmology, 96:865-74, 1989.

Noormohamed, F.H.; Youle, M.S.; Tang, B.; Martin-Munley, S.; Gazzard, B.G. \& Lant, A.F. Foscarnet-induced changes in plasma concentrations of total and ionized calcium and magnesium in HIV-positive patients. Antivir Ther., 1:172-9, 1996.

Paspaliaris, V.; Mai, X. \& Leaver, D.D. Foscarnet inhibits vascular smooth muscle contraction. Life Sci., 53:1227-34, 1993.

Sjovall, J.; Bergdahl, S.; Movin, G.; Ogenstad, S. \& Saarimaki, M.P. Pharmacokinetics of foscarnet and distribution to cerebrospinal fluid after intravenous infusion in patients with human immunodeficiency virus infection. Antimicrob. Agents Chemother, 33:23-31, 1989.

Sjovall, J.; Karlson, A.; Ogenstad, S.; Sandstrum, E. \& Saarimaki, M. Pharmacokinetics and absorption of foscarnet after intravenous and oral administration to patients with human immunodeficiency virus. Clin. Pharmacol. Ther., 44:65-73, 1988.

Tuntland, T.; Odinecs, A.; Pereira, C.M.; Nosbich, C. \& Unadkat, J.D. In vitro models to predict the in vivo mechanism, rate and extet of placental transfer of dideoxynucleoside drugs against human immunodeficiency virus. Am. J. Obstet. Gynecol., 180: 198-206, 1999.

Volberding, P.A. HIV therapy in 2003: consensus and controversy. AIDS, Suppl 1:S4-11, 2003.

Watts, DH. Antiviral agents. Obstet. Gynecol. Clin. North. Am., 19:563-85, 1992.

Winick, M. Cellular growth in intrauterine malnutrition. Pediatr. Clin. North Am., 17:69-75, 1970.

Correspondence to:

Prof. Dr. Cúcero Venneri Matfias

Received : 11-02-2005

Departamento de Obstetrícia.

Universidade Federal de São Paulo - ULNIFRESP/EPM

Rua Dr. Esdras Pacheco Ferreira, 143 Vila Nova Conceição

CEP 04507-060

Säo Paulo, SP. BRAZIL 